\title{
Bilateral renal artery thrombosis in inherited thrombophilia: a rare cause of acute kidney injury
}

This article was published in the following Dove Press journal: International Journal of Nephrology and Renovascular Disease 18 January 2014

Number of times this article has been viewed

\author{
Kate S Wiles' \\ Laura Hastings' \\ Vasantha Muthu \\ Muthuppalaniappan' \\ Muhammad Hanif ${ }^{2}$ \\ Sumith Abeygunasekara' \\ 'Department of Medicine, \\ ${ }^{2}$ Department of Radiology, Mid Essex \\ Hospital Services NHS Trust, \\ Chelmsford, UK
}

\begin{abstract}
We describe the case of a 47-year-old man who developed significant acute, and subsequently chronic, kidney injury due to bilateral renal infarction. This occurred in the context of a combined inherited thrombophilia including antithrombin III deficiency and a prothrombin gene mutation. Bilateral renal artery thrombosis developed despite prophylactic treatment for thromboembolism. Arterial thrombosis is rare in the context of inherited thrombophilia and bilateral renal infarction is an unusual cause of acute kidney injury. Bilateral renal infarction due to primary renal artery thrombosis has not been previously described in antithrombin III deficiency, either as an isolated defect or in combination with other hereditary thrombophilia. Keywords: renal infarction, renal thrombosis, AKI, antithrombin, prothrombin
\end{abstract}

\section{Introduction}

Antithrombin III is a plasma protein that inhibits several of the serine proteases involved in the coagulation cascade, including thrombin and factor Xa. It is therefore a major inhibitor of blood coagulation. A homozygous deficiency causes lethal thrombosis in utero or in the neonatal period; however, the heterozygous state occurs in $0.16 \%$ of the healthy population ${ }^{1}$ and in $1 \%-8 \%$ of those presenting with a thrombotic event. ${ }^{2}$

The link between heterozygous antithrombin III deficiency and venous thrombosis is well described. Thromboembolism typically presents as deep vein thrombosis of the limbs or pulmonary embolism, but can also occur in atypical venous sites, including the cerebral sinus, mesenteric, portal, hepatic, renal, and retinal veins. ${ }^{3}$ At 50 years, approximately $50 \%$ of individuals with antithrombin deficiency will have had an episode of venous thromboembolism. ${ }^{3}$ In contrast, antithrombin III deficiency leading to arterial thrombosis is rare.

Like antithrombin III, the 20210A allele of the prothrombin gene is a recognized risk factor for venous thromboembolism and is the second most common hereditary cause of venous thromboembolic disease. ${ }^{4}$ Its role in arterial thrombosis remains unclear, however, with studies both describing and refuting an association. ${ }^{5}$

We describe a rare case of acute kidney injury secondary to bilateral renal infarction in association with combined antithrombin III deficiency and a prothrombin gene mutation.

\section{Case report}

A 47-year-old male Caucasian farmworker presented with right-sided abdominal pain for the preceding 24 hours. Apart from mild nausea, there were no
Correspondence: Sumith Abeygunasekara Department of Nephrology Mid Essex Hospital Services NHS Trust Chelmsford, UK CMI 7ET

$\mathrm{Tel}+44$ I245 5I4 414

Email sumith.abeygunasekara@meht.nhs.uk submit your manuscript | www.dovepress.com

Dovepress

http://dx.doi.org/10.2147/IJNRD.S50948
International Journal of Nephrology and Renovascular Disease 20I4:7 35-38

(c) (i) (5) 2014 Wiles et al. This work is published by Dove Medical Press Limited, and licensed under Creative Commons Attribution - Non Commercial (unported, v3.0) License. The full terms of the license are available at http://creativecommons.org/licenses/by-nc/3.0/. Non-commercial uses of the work are permitted without any further permission from Dove Medical Press Limited, provided the work is properly attributed. Permissions beyond the scope of the License are administered by Dove Medical Press Limited. Information on how to request permission may be found at: http://www.dovepress.com/permissions.php 
other associated symptoms. He was known to have antithrombin III deficiency, with functional antithrombin III having been previously quantified at $48 \%$ (normal pooled plasma activity $83 \%-128 \%$ ). In addition, he was known to be heterozygous for the prothrombin (G20210A) gene mutation. He was taking aspirin $75 \mathrm{mg}$ daily. He had no history of thromboembolism or hypertension. He had no vascular risk factors, including diabetes, dyslipidemia, or a history of smoking.

On examination, he was apyrexial. His blood pressure measured 159/88 mmHg. He had right-sided flank tenderness with no rebound or guarding. Bowel sounds were normal. Urine dip revealed $2+$ protein but no blood. Creatinine was $1.02 \mathrm{mg} / \mathrm{dL}(90 \mu \mathrm{mol} / \mathrm{L})$. Neutrophils were moderately raised at $9.4 \times 10^{9} / \mathrm{L}$. CRP (C-reactive protein) was unremarkable at $1.7 \mathrm{mg} / \mathrm{L}$. His pain was managed with paracetamol (acetaminophen) and a single dose of $50 \mathrm{mg}$ diclofenac. Aspirin was withheld and he was given a daily prophylactic dose of enoxaparin $40 \mathrm{mg}$. Within 24 hours, his abdominal pain had localized to the right iliac fossa and he underwent appendectomy. Intraoperatively, his blood pressure fell to 100/50, requiring intravenous fluid resuscitation. Postoperatively, his abdominal pain settled. He was discharged home the following day with a blood pressure of $125 / 75 \mathrm{mmHg}$ and a creatinine level of $1.17 \mathrm{mg} / \mathrm{dL}(103 \mu \mathrm{mol} / \mathrm{L})$.

The patient was readmitted 4 days later with sudden-onset, severe left-sided abdominal pain. He was apyrexial. Blood pressure measured 150/80 mmHg. Examination revealed left-sided abdominal tenderness without rebound or guarding. Bowel sounds were normal. Urine testing revealed new microscopic hematuria. Inflammatory markers were raised with a neutrophil count of $11.7 \times 10^{9} / \mathrm{L}$ and a CRP level of $43.5 \mathrm{mg} / \mathrm{L}$. Creatinine had increased to $1.62 \mathrm{mg} / \mathrm{dL}(143 \mu \mathrm{mol} / \mathrm{L})$. Computed tomography with oral contrast revealed an $85 \times 35 \mathrm{~mm}$ collection at the appendectomy site. Significant left-sided perinephric stranding was also seen (Figure 1). He was treated for a postoperative intra-abdominal collection with intravenous co-amoxiclav and metronidazole. Prophylactic enoxaparin $40 \mathrm{mg}$ was given daily. Despite treatment, his inflammatory markers continued to climb, with CRP peaking at $363.9 \mathrm{mg} / \mathrm{L}$. In addition, his hematuria became macroscopic and his renal function declined to a creatinine level of $2.85 \mathrm{mg} / \mathrm{dL}$ ( $252 \mu \mathrm{mol} / \mathrm{L}$ ), equating to an estimated glomerular filtration rate (GFR) of $22 \mathrm{~mL} / \mathrm{min} / 1.73 \mathrm{~m}^{2}$. Anti-neutrophil cytoplasmic antibody (ANCA), double-stranded DNA (dsDNA) and anti-glomerular basement membrane antibody (anti-GBM) were negative. Immunoglobulins were normal and Bence Jones protein was not present in the urine. Nuclear medicine

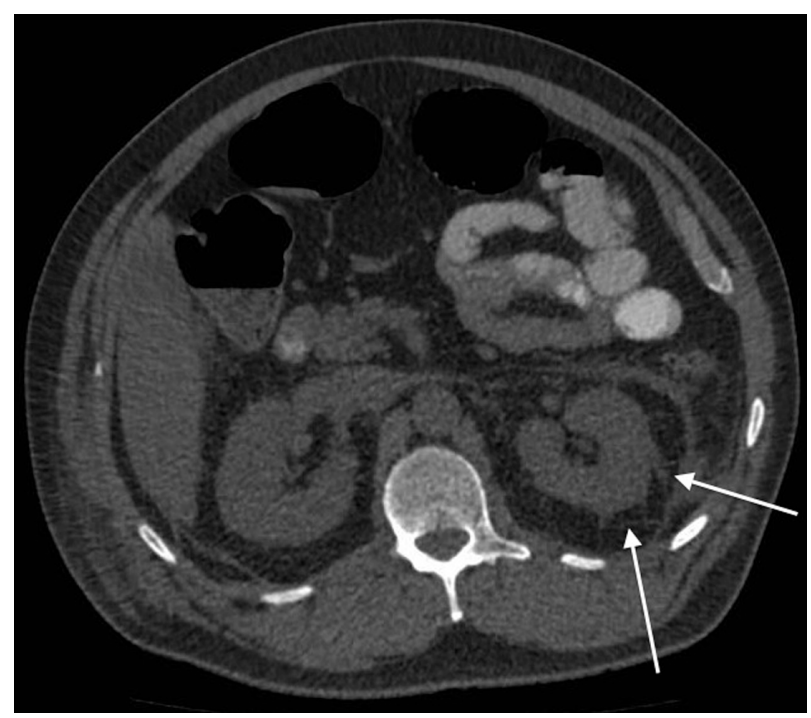

Figure I Computed tomography showing left perinephric stranding (arrows).

renography confirmed a significant kidney injury, showing a GFR of $21.72 \mathrm{~mL} /$ minute. It also demonstrated areas of poor uptake in the right kidney. Computed tomography angiography confirmed large bilateral renal infarcts with occluding thrombus visible in the left renal artery (Figure 2). Computed tomography and echocardiography excluded left ventricular and aortic thrombi. The patient was commenced on life-long warfarin therapy.

Six months later, his creatinine had stabilized to $1.98 \mathrm{mg} / \mathrm{dL}(175 \mu \mathrm{mol} / \mathrm{L})$, equating to an estimated GFR of $36 \mathrm{~mL} / \mathrm{min} / 1.73 \mathrm{~m}^{2}$. Blood pressure control required treatment with a combination of three agents. Urinary protein:creatinine ratio measured $698 \mathrm{mg} / \mathrm{g}$ and microscopic hematuria persisted.

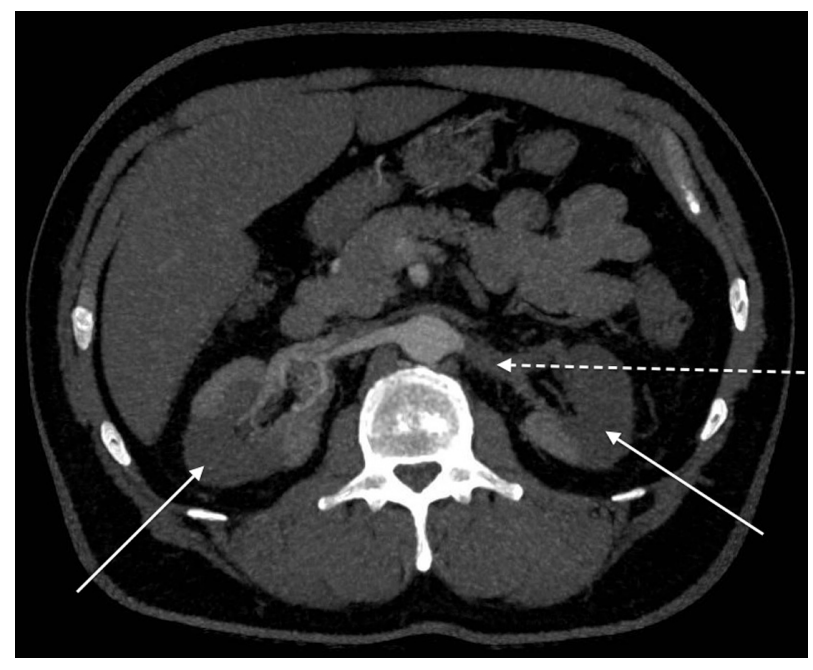

Figure 2 Computed tomography showing bilateral renal infarcts (arrows) and left renal artery occlusion (broken arrow). 


\section{Discussion}

Antithrombin III deficiency leading to arterial thrombosis is rare. A study of inherited thrombophilia including 34 families with antithrombin deficiency and 3,372 patient years of follow-up revealed only four cases of first-episode arterial thrombosis, specifically two cerebrovascular events and two myocardial infarctions. ${ }^{6}$ This represents an arterial thrombosis incidence of $0.09 \%$ per year. The presence of other vascular risk factors in these probands was not discussed in the study, however, and, if taken into account, the actual rate of arterial thrombosis attributable to the congenital coagulopathy may be even lower.

Nonrenal arterial thrombosis in association with antithrombin III deficiency is described in only a handful of case reports. Two cases of aortic thrombosis were published in $1981 .^{7}$ Cerebral infarction is documented in a 21 -year-old male $^{8}$ and in two sisters aged 27 and 40 years. ${ }^{9}$ Recurrent transient ischemic attacks from the age of 28 years have been recorded in a fourth patient. ${ }^{10}$ Hepatic infarction has also been described. ${ }^{11}$ Recurrent femoral artery thrombosis has been recorded in a teenager with antithrombin III deficiency but, in this case, the clinical picture was complicated by the presence of a bicuspid aortic valve causing left ventricular stasis and cardiac thrombosis. ${ }^{12}$ It could therefore be argued that the cardiac abnormality and resultant hemostasis mimicked venous thrombosis, with subsequent embolism rather than a primary arterial event.

Published literature reveals the rarity of renal artery disease in association with antithrombin III deficiency. Only two previous cases of renal artery occlusion and infarction are described; however, both occurred as embolic events from aortic thrombus rather than the primary renal artery occlusion described here. ${ }^{13,14} \mathrm{~A}$ third case from 1970 predates antithrombin III quantification, which can therefore only be hypothesized with the observation of numerous visceral infarcts, including renal infarction, found at autopsy. ${ }^{15}$ Although this patient's mother and four siblings were later found to be deficient in antithrombin III, the patient described was a smoker with known albuminuria and, in addition to renal infarction, extensive atheroma was evident in the aorta and coronary and pulmonary vasculature.

In addition to antithrombin III deficiency, our patient was also heterozygous for a prothrombin gene variant resulting from a guanine-to-adenine transition at position 20210. Published literature links only two cases of renal infarction to the prothrombin 20210A gene. The first is a paradoxical embolus in association with a patent foramen ovale and, therefore, renal artery thrombosis did not occur as a primary event. ${ }^{16}$ A second case report by Fraile et al describes renal infarction in a patient with a combined thrombophilic hereditary defect including prothrombin G20210A, this time in conjunction with a mutation in methylenetetrahydrofolate reductase. ${ }^{17}$ In this case, however, the patient had preexisting vascular risk factors, including hypertension, dyslipidemia, and a smoking history, as well as significant vascular comorbidity, including cerebral and cardiac disease.

The present case describes acute renal infarction in association with two different heritable coagulopathies and a perioperative hypotensive event. This represents a very rare cause of acute kidney injury. Published literature to date describes renal infarction in the context of hereditary thrombophilia as either a secondary embolic phenomenon or occurring in the context of vasculopathy. ${ }^{13-17}$ Primary renal artery thrombosis in the absence of underlying vascular disease has not previously been described.

The possibility of a synergistic relationship between the two different hereditary thrombophilic states in this case remains theoretical. The low number of patients with a double coagulation defect, in conjunction with the rarity of an arterial thrombotic event, means that conclusions cannot be made about the absolute level of thrombotic risk in combined hereditary thrombophilia. Rather, this case demonstrates the complexity of thrombophilia with both inherited and acquired risk factors interacting to produce a thrombotic phenotype. In the clinical setting of thrombophilia imparting a significant thrombotic risk, the authors recommend that a therapeutic, rather than prophylactic, dose of anticoagulant be considered to prevent significant morbidity.

\section{Disclosure}

The authors report no conflicts of interest in this work.

\section{References}

1. Tait RC, Walker ID, Perry DJ, et al. Prevalence of antithrombin deficiency in the healthy population. Br J Haematol. 1994;87:106-112.

2. Kottke-Marchant K, Duncan A. Antithrombin deficiency: issues in laboratory diagnosis. Arch Pathol Lab Med. 2002;126:1326-1336.

3. Patnaik MM, Moll S. Inherited antithrombin deficiency: a review. Haemophilia. 2008;14:1229-1239.

4. Schafer AI. Thrombotic disorders: hypercoagulable states. In: Goldman L, Bennet JC, editors. Cecil Textbook of Medicine. 21st ed. Philadelphia, PA: WB Saunders; 2000.

5. Moster ML. Coagulopathies and arterial stroke. J Neuroophthalmol. 2003;23(1):63-71.

6. Bucciarelli P, Rosendaal FR, Tripodi A, et al. Risk of venous thromboembolism and clinical manifestations in antithrombin, protein $\mathrm{C}$, protein $\mathrm{S}$ deficiency, or activated protein $\mathrm{C}$ resistance: a multicenter collaborative family study. Arterioscler Thromb Vasc Biol. 1999;19: 1026-1033.

7. Shapiro ME, Rodvien R, Bauer KA, Salzman EW. Acute aortic thrombosis in antithrombin III deficiency. JAMA. 1981;245(17):1759-1761. 
8. Shimizu K, Toriyama F, Ogawa F, Katayama I, Okajima K. Recurrent leg ulcers and arterial thrombosis in a 33-year-old homozygous variant of antithrombin. Am J Hematol. 2001;66:285-291.

9. Johnson EJ, Prentice CR, Parapia LA. Premature arterial disease associated with familial antithrombin III deficiency. Thromb Haemost. 1990;63:13-15.

10. Arima T, Motomura M, Nishiura Y, et al. Cerebral infarction in a heterozygote with variant antithrombin III. Stroke. 1992;23:1822-1825.

11. Emmanuelle T, Husein B, Iqbal J, Macheta M, Isaacs P. Concomitant homozygosity for the prothrombin gene variant with mild deficiency of antithrombin III in a patient with multiple hepatic infarctions: a case report. J Med Case Rep. 2010;4:122.

12. Coller BS, Owen J, Jesty J, et al. Deficiency of plasma protein S, protein C, or antithrombin III and arterial thrombosis. Arteriosclerosis. $1987 ; 7(5): 456-462$
13. Marcu CB, Donohue TJ, Ghantous AE. Spontaneous aortic thrombosis and embolization: antithrombin deficiency and the work-up of hypercoagulable states. CMAJ. 2005;173(9):1027-1029.

14. Calcaterra D, Martin JT, Ferneini AM, et al. Acute mesenteric and aortic thrombosis associated with antithrombin deficiency: a rare occurrence. Ann Vasc Surg. 2010;24(3):415. e5-e7.

15. Winter J, Donald D, Bennet B, Douglas AS. Arterial thrombosis and accelerated atheroma in a member of a family with familial antithrombin III deficiency. Postgrad Med J. 1982;58:108-109.

16. Vilbert EM, Franciosa SV. Acute renal failure with heritable coagulopathy and patent foramen ovale. Radiol Case Rep. 2009;4(1);260.

17. Fraile P, Garcia-Cosmes P, Lerma JL, et al. A 48 year old male with renal infarction and thrombophilia. Nefrologia. 2008;28(4):463-464.

\section{Publish your work in this journal}

The International Journal of Nephrology and Renovascular Disease is an international, peer-reviewed open-access journal focusing on the pathophysiology of the kidney and vascular supply. Epidemiology, screening, diagnosis, and treatment interventions are covered as well as basic science, biochemical and immunological studies. The journal welcomes original research, clinical studies, reviews \& evaluations, expert opinion and commentary, case reports and extended reports. The manuscript management system is completely online and includes a very quick and fair peerreview system, which is all easy to use. Visit http://www.dovepress.com/ testimonials.php to read real quotes from published authors.

Submit your manuscript here: http://www.dovepress.com/international-journal-of-nephrology-and-renovascular-disease-journal 